\title{
Destruction of Indoleacetic Acid
}

\author{
IV. Kinetics of Enzymic Oxidation ${ }^{1}$
}

\begin{abstract}
PETER M. RAY
From the Department of Botany, University of Michigan, Ann Arbor, Michigan

Received September 15, 1961

Kinetics of enzymic oxidation of indoleacetic acid (IAA) are interpreted as indicating that the reaction has an autocatalytic, cyclical mechanism involving unstable intermediates whose formation and disappearance are important in determining the over-all reaction rate. The kinetics do not support the idea that IAA oxidation occurs mainly by reaction with $\mathrm{Mn}^{+3}$, nor that the reaction is an electron transfer from IAA to $\mathrm{O}_{2}$ catalyzed by a peroxidase $-\mathrm{H}_{2} \mathrm{O}_{2}-\mathrm{Mn}^{+2}$ complex, nor that $\mathrm{Mn}$ is essential to the reaction. $\mathrm{H}_{2} \mathrm{O}_{2}$ is probably not a major reaction intermediate. One-electron oxidation of IAA by peroxidase giving a free radical, followed by spontaneous reaction of the radical with oxygen to give a peroxy oxidant which can reoxidize the peroxidase to a peroxide complex, appears to be a likely mechanism.
\end{abstract}

\section{INTRODUCTION}

Oxidation of indoleacetic acid (IAA), catalyzed by enzyme preparations containing peroxidase, has been interpreted in terms of cyclical mechanisms involving the utilization and production of hydrogen peroxide or other intermediates $(3,4,6,9,15$, 19). This paper presents a kinetic study of the IAA-oxidizing reaction catalyzed by a peroxidase from the fungus Omphalia favida. It considers the principles by which the rate of such a cyclical mechanism is determined and attempts to distinguish between different types of mechanisms which have been proposed for the reaction.

\section{METHODS}

The indoleacetic acid (IAA)-oxidizing enzyme of Omphalia flavida was prepared as described earlier (13). IAA oxidation was followed spectrophotometrically at $261 \mathrm{~m} \mu$ (12), using a Beckman IU spectrophotometer or a Cary recording spectrophotometer equipped with a $0-0.1$ optical density

\footnotetext{
${ }^{1}$ Some of the experiments described here were done while the author was a member of the Society of Fellows, Harvard University. These received support from National Science Foundation Grant XSF G-182 to Professor K. V. Thimann.
}

range slidewire. The Salkowski reagent of Gordon and Weber (5) was used to determine IAA where indicated.

Assay for Mn was performed as follows [cf. (14)]. The sample was evaporated and ashed in a (quartz crucible at red heat for $1.5 \mathrm{hr}$. in a muffle furnace. The slight residuc of white ash was taken u1 and evaporated to dryness three times in 0.3 $\mathrm{ml}$. of conc. $\mathrm{HNO}_{3}$, and then dissolved in $0.2 \mathrm{ml}$. water. Duplicate drops were placed on a spot plate along with duplicate drops of $\mathrm{MnSO}_{4}$ solutions between $10^{-6}$ and $10^{-5} M$. To each, 1 drop of $5 \%$ $\mathrm{NaIO}_{4}$ and 1 drop of $2 \mathrm{~N}$ acelic acid were added, the plate was shaken to mix the reagents, and after 5 min. 1 drop of $1 \% \quad p, p^{\prime}$-methylenebis$N, N$-dimethylaniline (Eastman) in acetone was added. A $10^{-6} \mathrm{M}$ solution of $\mathrm{MnSO}_{4}$ gave a detectable blue color immediately. The concentration of $\mathrm{Mn}$ in the sample drops was estimated by comparison with the standards.

Enzyme reactions were conducted at room temperature (about $23^{\circ} \mathrm{C}$.), in $5 \mathrm{~m} . M$ sodium citrate buffer, $\mathrm{pH} 3.7$, unless indicated otherwise.

\section{EXPERIMENTAL AND RESUITS}

\section{The Indection Erfect}

In manometric experiments with the Omphalia enzyme, a lag of about $5 \mathrm{~min}$. after IAA was added preeced the attain- 


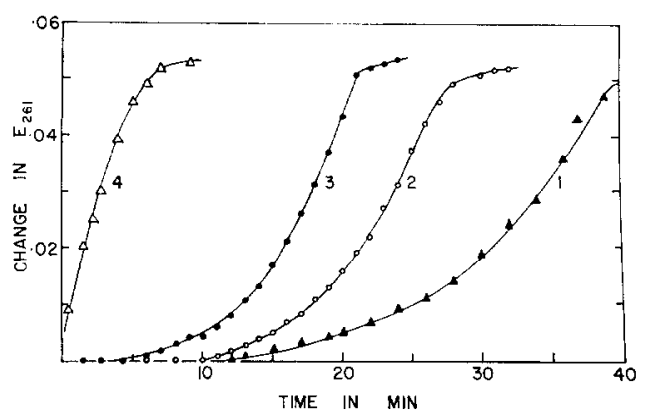

FIg. 1. Effect of enzyme concentration and $\mathrm{H}_{2} \mathrm{O}_{2}$ on induction phase. To $3 \mathrm{ml}$. citrate buffer containing $0.137 \mu$ mole IAA the following amounts of enzyme were added: curve $1,0.12 \mathrm{ml}$; curve $2,0.2$ $\mathrm{ml}$; curves 3 and $4,0.3 \mathrm{ml}$. The sample in curve 4 contained, in addition, $8 \mathrm{~m} \mu$ moles $\mathrm{H}_{2} \mathrm{O}_{2}$.

ment of a steady rate of $\mathrm{O}_{2}$ uptake and $\mathrm{CO}_{2}$ production. Under the more dilute conditions used in spectrophotometric measurement, this induction phase lasted longer and could be followed more precisely. Figure 1 shows the progress of the reaction at three different enzyme concentrations (curves 1-3). The amount of IAA was small enough that a steady rate had not been reached by the time all the IAA had been oxidized.

The following observations indicate that the induction phase is not due to inhibitors present in the preparation $[\mathrm{cf} .(6,10,11$, 18)]: (a) The induction phase was accelerated by increasing the enzyme concentration. (b) Enzyme preparations at all stages of purification (13) showed the induction effect. (c) Addition of boiled enzyme preparations did not extend the induction phase. (d) The induction phase was repeated when more IAA was added to a sample of enzyme after the initially added IAA had been oxidized.

The latter experiment is shown in Fig. 2. IAA oxidation was followed at $288.5 \mathrm{~m} \mu$, where extinction decreases as IAA is oxidized, so it was possible to make measurements after a second addition of IAA. When more IAA was added just before that originally present had been used up (curve 1), a rapid reaction continued; but when IAA was added several minutes after the first reaction had ceased, an induction phase rather similar to that which had occurred initially was observed (curve 2). Had the first induction phase been due to progressive inactivation of an inhibitor, no induction phase should have been observed when more IAA was added.

The different behavior of samples 1 and 2 in Fig. 2 may be understood by considering that the increase in reaction rate during induction is due to a gradual increase in concentration of reaction intermediates upon which the rate of a cyclical mechanism depends. These intermediates were still present at the time more IAA was added to sample 1, but had largely disappeared by the time it was added to sample 2 . The process by which the concentration of ratecontrolling intermediates increases will be referred to as initiation.

That the reaction rate gradually approaches a steady value can probably be ascribed to processes which limit the concentration of active intermediates which can be attained in the system. There is indication in the experiment of Fig. 2 of reactions leading to the disappearance of these intermediates. When the rate of disappearance becomes equal to the rate of formation of intermediates, a "steady state" of constant IAA oxidation rate should ensue. Reactions leading to loss of intermediates will be called termination reactions.

\section{EFFECT OF $\mathrm{H}_{2} \mathrm{O}_{2}$}

In Fig. 1, curve 4 shows what happens if a small amount of $\mathrm{H}_{2} \mathrm{O}_{2}$ is added to the same system as in curve 3 . A rapid reaction occurs immediately and proceeds to completion without increase in rate. $\mathrm{H}_{2} \mathrm{O}_{2}$ either is, or is convertible into, one of the reaction intermediates. Figure 3 shows how the initial reaction rate depended upon concentration of added $\mathrm{H}_{2} \mathrm{O}_{2}$. The rate increased rapidly up to about $5 \times 10^{-6} M$, above which it reached a plateau and can be said to be saturated in respect to $\mathrm{H}_{2} \mathrm{O}_{2}$. Ratesaturating concentrations of $\mathrm{H}_{2} \mathrm{O}_{2}$ caused negligible destruction of IAA in the absence of the enzyme.

The complex spectroscopic changes which accompany IAA oxidation (12) were closely similar in the presence and absence of added $\mathrm{H}_{2} \mathrm{O}_{2}$. The amount of IAA destroyed when 
$\mathrm{H}_{2} \mathrm{O}_{2}$ was added was many times greater than the amount of $\mathrm{H}_{2} \mathrm{O}_{2}$ added (see below), and the reaction required $\mathrm{O}_{2}$ and consumed it stoichiometrically $(12,13)$. Therefore, the rapid reaction which occurs when $\mathrm{H}_{2} \mathrm{O}_{2}$ is added is not due to a distinct "peroxidativc" rcaction but is simply an increase in the reaction rate. Saturating amounts of $\mathrm{H}_{2} \mathrm{O}_{2}$ raise the rate to several times the steady-state value. However, amounts of $\mathrm{H}_{2} \mathrm{O}_{2}$ much in excess of saturation are inhibitory.

It was shown previously (13) that the IAA-oxidizing enzyme of Omphalia flavida is a peroxidase. Therefore, added $\mathrm{H}_{2} \mathrm{O}_{2}$ most likely promotes IAA oxidation by reacting with the enzyme. The $\mathrm{H}_{2} \mathrm{O}_{2}$ saturating rate is then determined by the rate of the enzyme-catalyzed step when the enzyme is saturated with $\mathrm{H}_{2} \mathrm{O}_{2}$, the enzyme not being saturated in the steady state.

Addition of catalase inhibited IAA oxidation, as measured manometrically (steady state), but rather large amounts were required. For example, $0.4 \mathrm{mg}$. of Armour 30 catalase slowed the induction phase and reduced the steady state $Q_{\mathrm{O}_{2}}$ from $312 \mu \mathrm{l}$./ hr. to $161 \mu \mathrm{l} . / \mathrm{hr}$. using $1 \mathrm{ml}$. of Omphalia enzyme and $12.8 \mu$ moles IAA at $p H 3.7$ (catalase activity was shown to be stable under these conditions). The same amount of boiled catalase had no effect. However, much larger amounts of catalase did not completely suppress IAA oxidation, as one might have expected were $\mathrm{H}_{2} \mathrm{O}_{2}$ a reaction intermediate.

Although the results with catalase suggest that $\mathrm{H}_{2} \mathrm{O}_{2}$ may be involved in the reaction to some extent, neither they nor the promotive action of $\mathrm{H}_{2} \mathrm{O}_{2}$ itself allow one to conclude that $\mathrm{H}_{2} \mathrm{O}_{2}$ is a major reaction intermediate.

\section{Enzyme and Substrate Concentration}

Both in the steady state and in the presence of a saturating amount of $\mathrm{H}_{2} \mathrm{O}_{22}$, the relation between reaction rate and enzyme concentration was somewhat less than linear, but considerably more than in proportion to square root of enzyme concentration.

In the presence of added $\mathrm{H}_{2} \mathrm{O}_{2}$, the reac- tion rate was quite independent of IAA concentration down to about $4 \times 10^{-5} \mathrm{M}$. In the absence of added $\mathrm{H}_{2} \mathrm{O}_{2}$, increases in IAA above this concentration had a small effect on the reaction rate, as seen spectro-

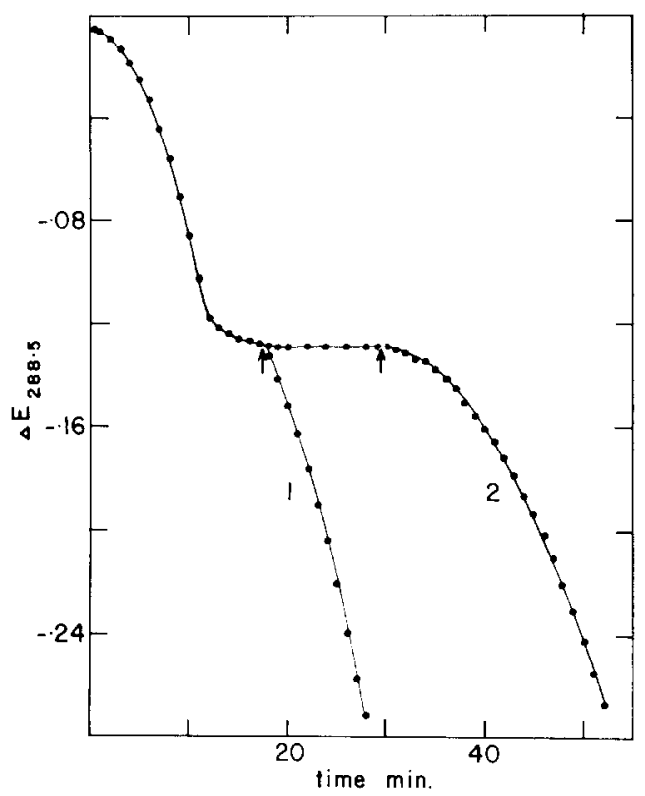

Fic. 2. Induction effect after cessation of IAA oxidation. At the start $0.2 \mathrm{ml}$. enzyme solution was added to $0.27 \mu$ mole IAA in $3 \mathrm{ml}$. citrate buffer. At the arrows, $0.27 \mu$ mole more IAA was added to curette 1 or 2. Optical density corrected for change upon adding IAA. Under the conditions, $288.5 \mathrm{~m} \mu$ was a wavelength at which extinction ceased to change when the IMA was used up, so that IAA oxidation could be followed without interference from secondary reactions (12).

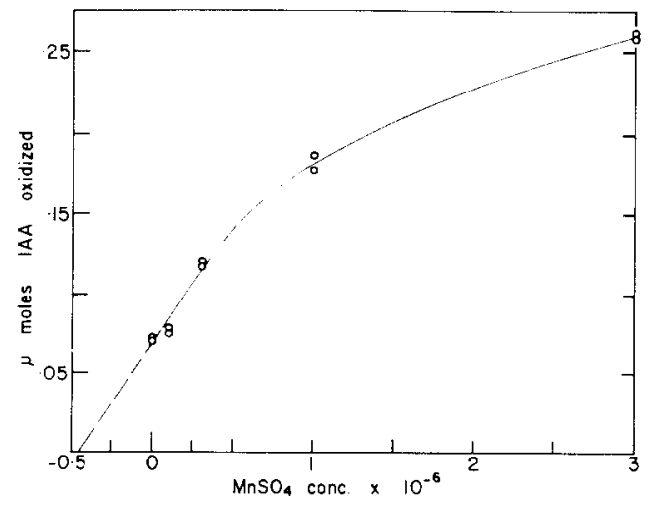

FIG. 3. Effect of added $\mathrm{H}_{2} \mathrm{O}_{2}$ on rate of IAA oxidation. Initial rate of increase in optical density at $261 \mathrm{~m} \mu$ shown on ordinate. 


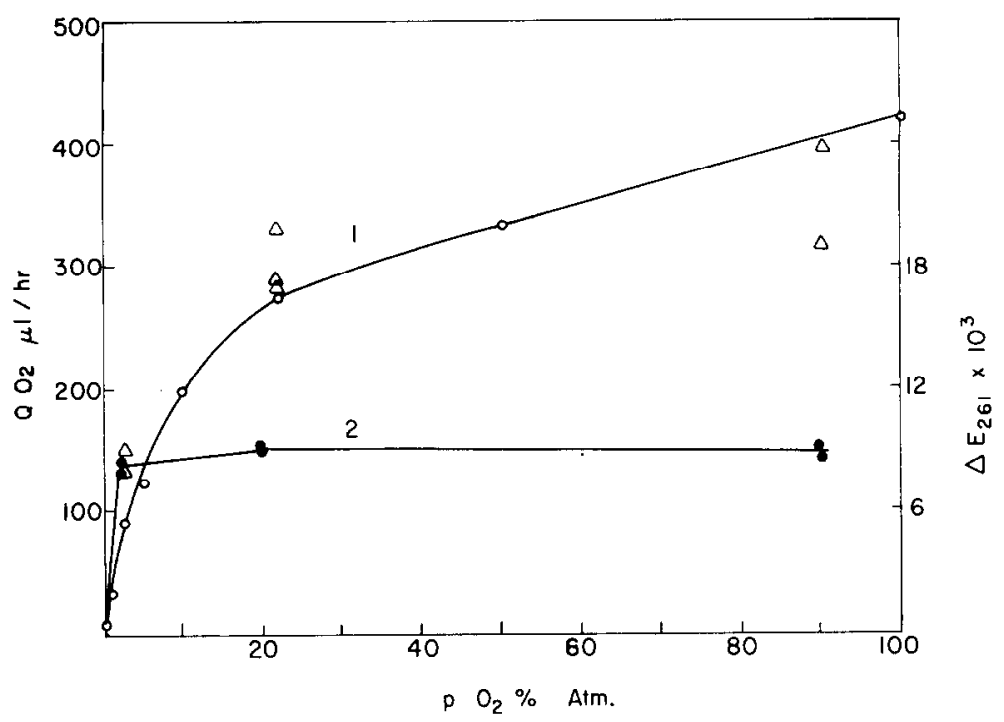

FIG. 4. Effect of oxygen concentration on IAA oxidation. Curve 1 (open circles, left-hand ordinate), $Q_{\mathrm{O}_{2}}$ measured manometrically ( $19 \mu$ moles IAA, $2.2 \mathrm{ml}$. of $0.05 M$ citrate containing $1 \mathrm{ml}$. enzyme). Triangles, increase in $E_{281} \times 1 / 2$ (right-hand ordinate) in first $15 \mathrm{~min}$. of induction phase $(0.3 \mu$ mole IAA, $0.1 \mathrm{ml}$. enzyme, in $3 \mathrm{ml}$. of $5 \mathrm{~m} M$ citrate). Curve 2 (righthand ordinate), increase in $E_{201}$ per min., under conditions similar to the preceding, but 15 mumoles $\mathrm{H}_{2} \mathrm{O}_{2}$ added. Vessels gassed with appropriate mixtures of $\mathrm{O}_{2}$ and $\mathrm{N}_{2}$ before addition of enzyme.

photometrically. In manometric experiments strong dependence of reaction rate on IAA at much higher concentrations was usually observed. Although the results of some experiments corresponded well with Michaelis-Menten kinetics, different experiments were not quantitatively consistent, and it is felt that the manometric results do not afford a measure of the "affinity" of the system for IAA. They may be due to sec-

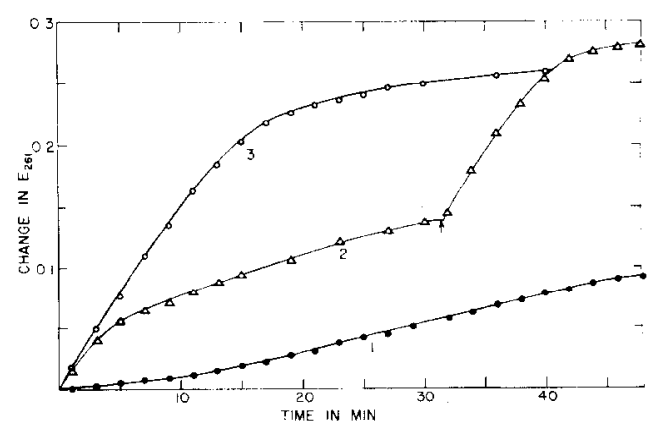

Fia. 5. Changes in reaction rate after $\mathrm{H}_{2} \mathrm{O}_{2}$ is added. Amounts added initially : curve 1, no $\mathrm{H}_{2} \mathrm{O}_{2}$; curve 2, $10 \mathrm{~m} \mu$ moles $\mathrm{H}_{2} \mathrm{O}_{2}$; curve $3,50 \mathrm{~m} \mu$ moles $\mathrm{H}_{2} \mathrm{O}_{2}$. At arrow, 50 m $\mu$ moles $\mathrm{H}_{2} \mathrm{O}_{2}$ added to sample 2 . ondary effects upon the steady state, or to effects on initiation.

The pronounced effect of uxygen concentration on the steady state, measured manometrically, is shown in curve 1 of Fig. 4. Increase in oxygen concentration accelerated the rate also under the conditions used in spectrophotometric measurement (triangles in Fig. 4), but the effect was not as strong. Curve 2 of Fig. 4 shows that the reaction rate was independent of oxygen concentration over a wide range when a saturating concentration of $\mathrm{H}_{2} \mathrm{O}_{2}$ was added, even though oxygen was required.

\section{Disappearance of Added $\mathrm{H}_{2} \mathrm{O}_{2}$}

When an amount of $\mathrm{H}_{2} \mathrm{O}_{2}$ is added which gives a rate greater than the steady-state value, the initially rapid rate declines with time. This appears to be due to loss of $\mathrm{H}_{2} \mathrm{O}_{2}$ from the system, for the rapid rate can be restored by adding more $\mathrm{H}_{2} \mathrm{O}_{2}$. In Fig. 5 the sample in curve 1 received no $\mathrm{H}_{2} \mathrm{O}_{2}$; that in curve 3 received an amount several times in excess of saturation; while that in curve 2 received slightly less than the saturating amount. Its rate fell gradually to 
nearly the same value as was reached, after induction, in curve 1. Addition of more $\mathrm{H}_{2} \mathrm{O}_{2}$ at the arrow brought back the saturating rate.

The behavior noted in Fig. 5 would be expected if the steady value which the rates in eurves 1 and 2 both approach represented, as suggested previously, a "steady state" which arises when the rate of formation of active intermediates (initiation) is equal to the rate at which they are disappearing (termination). Above this reaction rate, termination exceeds initiation, and below it initiation exceeds termination. Because the loss of $\mathrm{H}_{2} \mathrm{O}_{2}$ observed when it is added may be caused by the same termination process, it was thought important to examine the loss of $\mathrm{H}_{2} \mathrm{O}_{2}$ quantitatively.

The rate at which $\mathrm{H}_{2} \mathrm{O}_{2}$ disappeared when IAA oxidation was proceeding at $\mathrm{H}_{2} \mathrm{O}_{2}$ saturation was determined by the kind of experiment shown in Fig. 6. The more the amount of $\mathrm{H}_{2} \mathrm{O}_{2}$ which was added, the longer the saturating reaction rate continued. The point at which the rate began to decline rapidly can be considered the time at which the $\mathrm{H}_{2} \mathrm{O}_{2}$ concentration had fallen below the saturating value. By dividing the amount of IAA destroyed in the interval between the bends in curves 1 and 2 by the difference in amount of $\mathrm{H}_{2} \mathrm{O}_{2}$ added to the two samples, we obtain the relative rates of IAA and $\mathrm{H}_{2} \mathrm{O}_{2}$ disappearance. This ratio was approximately 9 in the experiment of Fig. 6.

Table I shows the influence of varying the enzyme concentration upon the ratio of IAA oxidation to $\mathrm{H}_{2} \mathrm{O}_{2}$, disappearance. Sereralfold differences in enzyme concentration and reaction rate had very little effect on this ratio. This fact is useful in arriving at a kinetically suitable termination process.

\section{Kinetich of the Reaction Coerse}

During the early part of the induction phase, for example in Fig. 1, there was indication that acceleration increased as the reaction rate itself increased. This suggested that the initiation proess depended upon the IAA-oxidizing reaction, so that the reaction as a whole is autocatalytic.

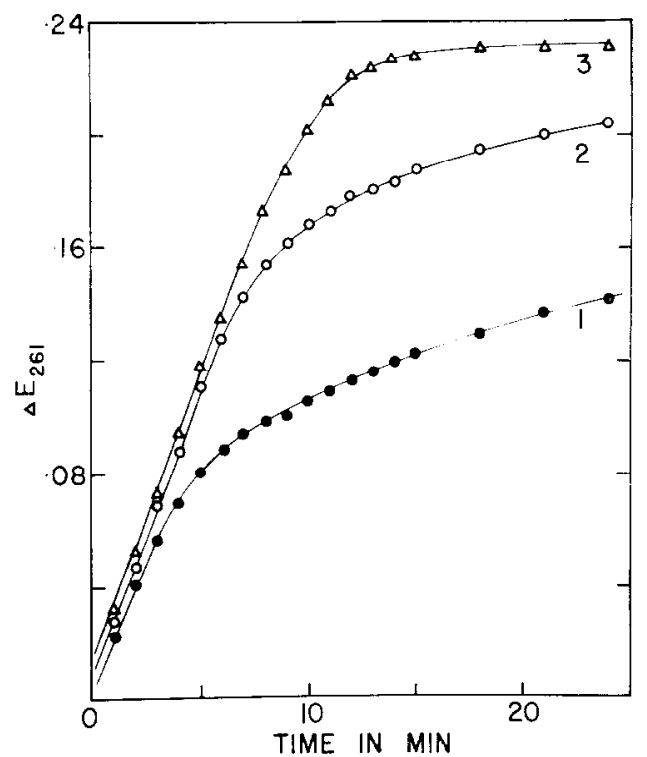

Fiti. 6. Method for measuring luse of $\mathrm{H}_{2} \mathrm{O}_{2}$ during reaction. Enzyme and $0.53 \mu$ mole $\mathrm{IAA}$ in $3 \mathrm{ml}$. containing: curve 1,20 mumoles $\mathrm{H}_{2} \mathrm{O}_{2}$; curve 2 . 40 mpmoles $\mathrm{H}_{2} \mathrm{O}_{2}$; curve 3,60 m $\mu$ moles $\mathrm{H}_{2} \mathrm{O}$. . In sample 3 reaction ended when all IAA was oxidized.

The steady state which follows the induction phase could be the result of termination increasing more than in proportion to initiation as the reaction rate increases, until the rate of termination becomes equal to the rate of initiation and the concentration of active intermediates becomes constant. It is interesting to consider the kinetics of a reaction whose steady state is determined in this manner.

There are reasons for thinking that some of the intermediates in IAA oxidation may be free radicals. In this case the principal

TABLE 1

EfFect of Exzyme Coxcentratiox on Ratio of IAA OXIDATION TO H,O. DISAPPEARANCE

\begin{tabular}{|c|c|c|c|}
\hline Expt. No. & Enzyme soln. & $\begin{array}{l}\text { Initial } \Delta E_{x+1} \\
\text { min. }\end{array}$ & $\frac{\mathrm{SIAA}}{\mathrm{S \textrm {H } _ { 2 } \mathrm { O } _ { 2 }}}$ \\
\hline & $m i$ & & \\
\hline \multirow[t]{2}{*}{1} & 0.33 & .013 & 9.7 \\
\hline & 0.90 & .029 & 9.0 \\
\hline \multirow[t]{2}{*}{2} & 0.33 & .011 & 10.7 \\
\hline & 1.00 & .031 & 10.4 \\
\hline
\end{tabular}


termination process may well be recombination of radicals, which would be of the second order.

We shall represent, with $[Z]$ the concentration of active intermediates upon which the reaction rate depends, and assume that IAA oxidation (governed by $k_{1}$ ) and initiation (governed by $k_{2}$ ) are proportional to $[Z] ; k_{3}$ is the rate coefficient for termination. The difference between initiation and termination is $d[Z] / d t=k_{2}[Z]-k_{3}[Z]^{2}$. This can be integrated to give

$$
[Z]=\frac{k_{2} e^{k_{2} t}}{k_{3} e^{k_{2} t}+k_{3} D}
$$

The factor $D$ is $\left(k_{2}-k_{3}\left[Z_{0}\right]\right) / k_{3}\left[Z_{0}\right]$, in which $\left[Z_{0}\right]$ is the concentration of active intermediates at zero time.

Since the reaction rate is practically independent of IAA concentration $([S])$, it may be written $d[S] / d t=-k_{1}[Z]$. Substitution for $[Z]$ and integration leads to

$\left[S_{0}\right]-[S]=\frac{k_{1}}{k_{3}} \ln \left(e^{k_{2} t}+D\right)+$ const.

This expression has the form $a \ln (b+$

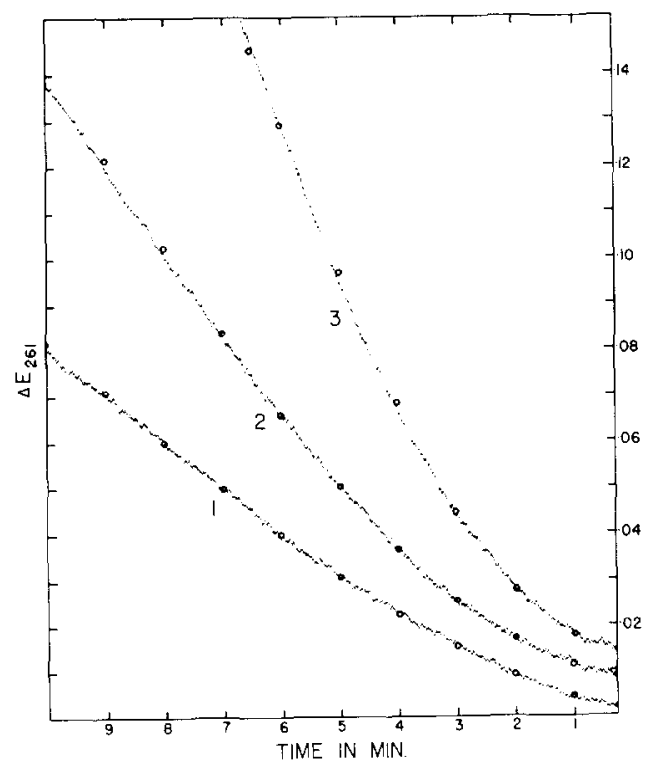

FIG. 7. Induction phase and steady state. Cary spectrophotometer records made with $0.46 \mu$ mole IAA in $2.7 \mathrm{ml}$. of $0.05 M$ citrate, $\mathrm{pH}$ 3.7. Curve 1 , $0.45 \mathrm{ml}$. enzyme; curve $2,0.9 \mathrm{ml}$; curve $3,1.8 \mathrm{ml}$. Circles are points calculated as described in text.
TABLE II

Values of Coefficients in EQ. (9)

Figures are in optical density units $(261 \mathrm{~m} \mu)$, and minutes, and apply to data of Fig. 11.

\begin{tabular}{|c|c|c|c|c|c|}
\hline $\begin{array}{c}\text { Expt. } \\
\text { No. }\end{array}$ & Enzyme & $\begin{array}{l}\text { Steady } \\
\text { state rate }\end{array}$ & $a$ & $b$ & $c$ \\
\hline & $m l$. & $\min ^{-1}$ & & & \\
\hline 1 & 0.45 & .011 & .025 & 2.8 & .46 \\
\hline 2 & 0.90 & .019 & .031 & 6.3 & .62 \\
\hline 3 & 1.80 & .034 & .035 & 10.3 & .95 \\
\hline
\end{tabular}

$e^{(t)}+$ const. One can determine whether Eq. (2) is consistent with the reaction kinetics by seeing whether values for $a, b$, and $c$ can be found which reproduce the experimentally observed reaction course. Figure 7 shows records of the induction phase and steady state obtained at three enzyme concentrations. The circles shown in this figure represent values of Eq. (2) computed for each curve using the coefficients listed in Table II, which were obtained by a trial and error method. A rather close fit with the experimental curves was obtained, suggesting that Eq. (3) may come near to describing the actual kinetics. While this does not prove that the reaction rate is determined in the manner suggested, it does seem striking that such a close correspondence with expectation could be obtained.

\section{Kinetic Role of the Enzyme}

Acceleration of the induction phase and steady state by the enzyme nearly in proportion to its concentration could be due to catalysis either of initiation or of the main oxidation. A direct test of whether the enzyme catalyzes initiation or the main reaction can be made by allowing the reaction to proceed through induction into the steady state, and then increasing the enzyme concentration by adding more enzyme. It can be shown from Eq. (2) that if changing the enzyme concentration affects $k_{2}$, the rate coefficient for initiation, and not $k_{1}$, the rate coefficient for the main reaction, then the time required for the reaction rate to increase to a new steady-state value (for example, to double) should be similar to the time taken for the rate to increase comparably (to double) during the later part 


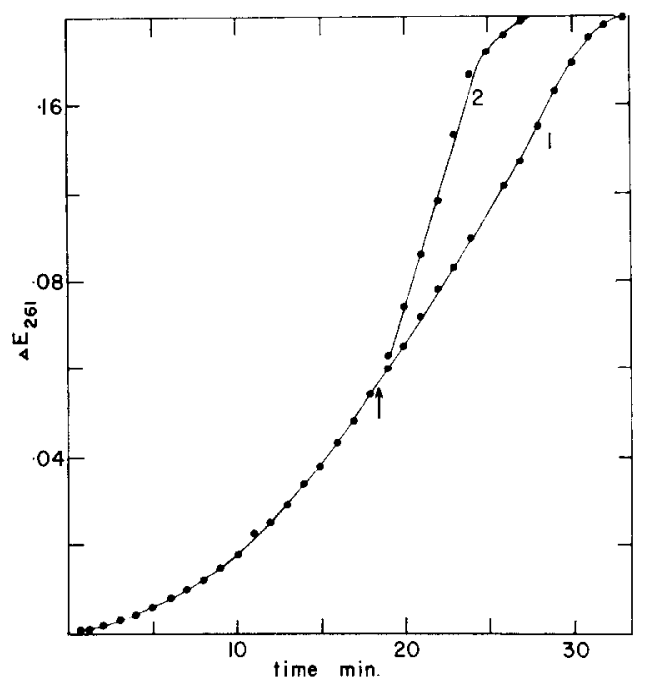

FIG. 8. Effect of changing the enzyme concentration. Induction was followed using $0.1 \mathrm{ml}$. enzyme in $3 \mathrm{ml}$. buffered $10^{-4} M$ IAA. Al arrow, 0.1 ml. more enzyme added to sample 2 .

of the induction phase. If $k_{1}$ is increased, on the other hand, the increase in reaction rate should be immediate.

This experiment, shown in Fig. 8, gave the latter result. It thus appears that the enzyme catalyzes the main reaction, and not initiation.

\section{Manganese and Phenols}

With the purified Omphalia enzyme, $\mathrm{Mn}^{+2}$ did not promote the reaction unless a monophenol such as resorcinol or 2,4dichlorophenol was also added. Figure $9 \mathrm{~A}$ shows that when $\mathrm{H}_{2} \mathrm{O}_{2}$ was not added, neither Mn nor phenol promoted by itself, but strong promotions could be obtained by combinations of the two. Promotive combinations accelerated both in the induction phase and in the steady state.

By contrast, when the effects of Mn and phenols were tested in the presence of a rate-saturating concentration of $\mathrm{H}_{2} \mathrm{O}_{2}$, it was found (Fig. 9B) that the phenol promoted substantially by itself, while Mn did not promote at any phenol concentration but had only an inhibitory action.

The concentration range in which 2,4 -dichlorophenol gave promotion depended upon pH. As shown in Fig. 10, the optimal con- centration was about two orders of magnitude lower at $\mathrm{pH} 6.5$ than at $\mathrm{pH} 3.7$.

That promotion by $\mathrm{Mn}$ is obtained only in the induction phase and steady state, and not at $\mathrm{H}_{2} \mathrm{O}_{2}$ saturation, suggests two possible explanations:

(a) $\mathrm{Mn}^{+2}$ promotes the reaction with $\mathrm{O}_{2}$, or some further step in the regeneration of the primary oxidant, which is not ratelimiting at $\mathrm{H}_{2} \mathrm{O}_{2}$ saturation. Such explanations have been proposed previously $(7,15$, 19).

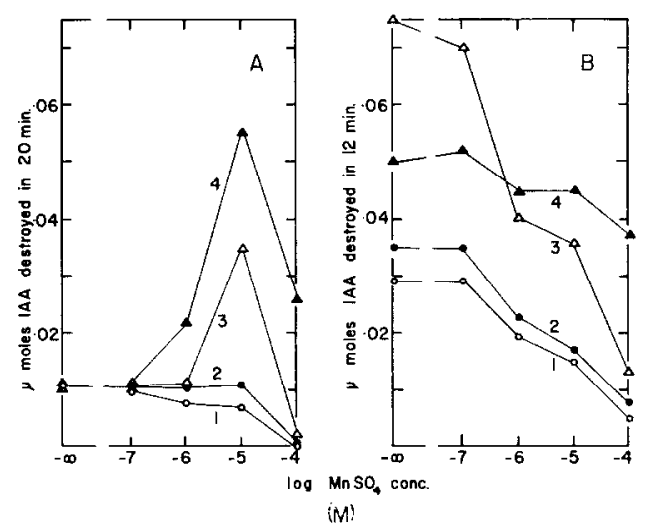

Fig. 9. Effects of $\mathrm{Mn}^{+2}$ and 2,4-dichlorophenol without $(A)$ and with $(B)$ added $\mathrm{H}_{2} \mathrm{O}_{2}$. Samples contained $90 \mathrm{~m} \mu$ moles IAA and $5 \mu \mathrm{I}$. enzyme in 1 $\mathrm{ml}$. of $0.05 M$ eitrate $\mathrm{pH} 3.7$; in Fig. $9 B$, also 6 m $\mu$ moles $\mathrm{H}_{2} \mathrm{O}_{2}$. Concentrations of 2,4-dichlorophenol: curve 1 , none; curve $2,10^{-5} \mathrm{M}$; curve 3 , $10^{-4} M$; curve $4,8 \times 10^{-4} M$. IAA determined with Salkowski reagent.

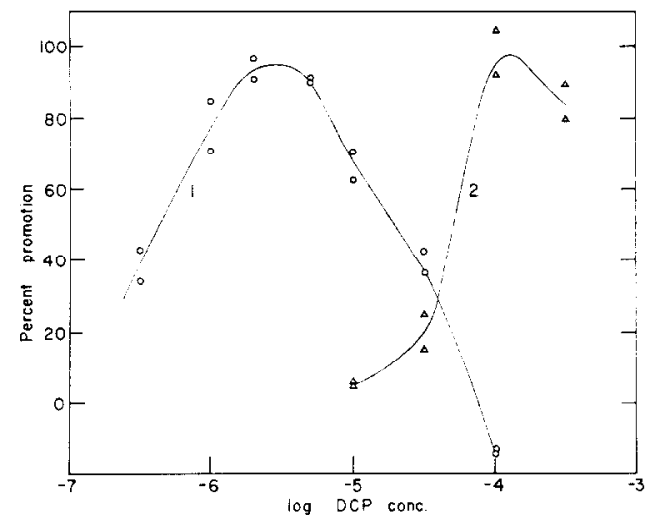

FIG. 10. Effect of 2,4-dichlorophenol in presence of $\mathrm{H}_{2} \mathrm{O}_{2}$. Curve 1 , in $0.05 M$ sodium phosphate, $\mathrm{pH}$ 6.5. Curve 2, in $0.05 M$ sodium citrate, $\mathrm{pH}$ 3.7 . 
(b) $\mathrm{Mn}^{+2}$ promotes initiation; the reaction rate should not depend upon initiation when the enzyme is $\mathrm{H}_{2} \mathrm{O}_{2}$-saturated. Optimal Mn-phenol combinations raised the steady-state rate nearly to that which could be obtained by adding $\mathrm{H}_{2} \mathrm{O}_{2}$; this suggests that they increase the concentration of active intermediates nearly to the $\mathrm{H}_{2} \mathrm{O}_{2}$ saturation level, by promoting initiation.

Maclachlan and Waygood (9) interpreted the promotive effects of Mn and phenols on enzymic IAA oxidation, and other evidence, as indicating that IAA is oxidized not by the cnzyme but by $\mathrm{Mn}^{+3}$, which is formed as a result of oxidation of a phenol by peroxidase. Kinetic analysis of the reaction sequence they proposed indicates that if it were operating, addition of $\mathrm{Mn}^{+2}$ could promote in the steady state but not at $\mathrm{H}_{2} \mathrm{O}_{2}$ saturation if and only if the concentration of phenol were large compared with the concentration of peroxy intermediate required to give saturation of the enzyme.

since phenol concentrations effective in bringing on promotion by $\mathrm{Mn}$ at $\mathrm{pH} 3.7$ (Fig. 9) were large compared with the ratesaturating concentration of $\mathrm{H}_{2} \mathrm{O}_{2}$, it was felt that the Mn oxidation proposal could be tested more critically by examining the effect of $\mathrm{Mn}$ in the presence of $10^{-6}$ M $2,4-$ dichlorophenol at $\mathrm{pH}$ 6.5. This low phenol concentration, less than the $2 \times 10^{-6} M$

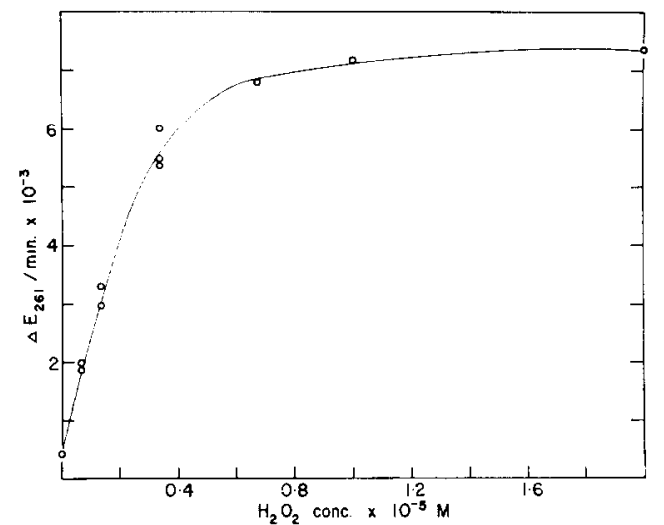

FIG. 11. Determination of threshold for $\mathrm{Mn}^{+2}$ promotion. Samples contained $0.3 \mathrm{ml}$. enzyme, $0.45 \mu$ mole IAA and $0.5 \mu$ mole 2 ,4-dichlorophenol in $5 \mathrm{ml}$. of $5 \mathrm{mM}$ ammonium citrate buffer $\mathrm{pH}$ 3.7. IAA determined by Salkowski assay after 12 min. of reaction.
$\mathrm{H}_{2} \mathrm{O}_{2}$ required for rate saturation, made possible large promotions by $10^{-6}$ and $10^{-5}$ $M \mathrm{MnSO}_{4}$ in the absence of added $\mathrm{H}_{2} \mathrm{O}_{2}$ at pH 6.5. However, not the slightest promotion was obtained, when $\mathrm{H}_{2}\left(\mathrm{O}_{2}\right.$ was present, by any $\mathrm{Mn}+2$ coneentration between $10^{-i}$ and $10^{-3} M$.

Therefore, the kinetics of $\mathrm{Mn}^{+2}$ action on the present system do not support the mechanism proposed by Maclachlan and Waygood (9). However, it seems possible that some of the reactions they suggested may be involved in the promotive effect of $\mathrm{Mn}^{+2}$ on initiation.

One can test kinctically whether $\mathrm{Mn}$ is essential to the reaction, by whatever mechanism. If Mn were essential, then the reaction which is observable in the absenee of added Mn must be due to endogenous Mn in the system, and a concentration of added $\mathrm{Mn}+2$ which promotes only slightly must be presumed to be less than the endogenous.

No Mn was detected either in the enzyme preparation, the IAA, or the citrate buffer, by spectrographic analyses performed through the courtesy of Dr. C. A. Price and Dr. B. L. Vallee.

In the following experiment the effect of added $\mathrm{Mn}^{+2}$ was compared directly with the Mn content of a particular reaction system, assayed by a very sensitive but less specific method. As shown in Fig. 11, an insignificant promotion was obtained at $10^{-7} M \mathrm{MnSO}_{4}$, and the apparent endogenous $\mathrm{Mn}$ concentration, assuming $\mathrm{Mn}$ is essential, appears from back extrapolation of the data to have been about $4 \times 10^{-7} M . A$ $225-\mathrm{ml}$. sample of the same reaction components was evaporated, ashed, and tester. for Mn by the procedure described under Methods. The color reaction obtained corresponded to $1-2 \times 10^{-6} M \mathrm{Mn}$ in the final $0.2-\mathrm{ml}$. sample or to $1-2 \times 10^{-9} M$ in the original reaction mixture.

Therefore, the endogenous Mn concentration was much too low to account for the threshold for promotion by added $\mathrm{Mn}$; one must conclude that the reaction in the absence of added Mn does not depend upon endogenous $\mathrm{Mn}$ and that $\mathrm{Mn}$ is not essential. 


\section{DISCUSSION}

The bearing of the kinetics on the principal types of mechanisms which have been suggested for IAA oxidation and related oxygen-consuming reactions catalyzed by peroxidases, other than the Mn oxidation hypothesis considered in the last section, will now be discussed. These are:

(a) Coupled action of a peroxidase and an oxidase, the latter forming $\mathrm{H}_{2} \mathrm{O}_{2}$ (or some other peroxide) from $\mathrm{O}_{2}$, and the for.mer using this peroxide as substrale $(3,15)$.

(b) One-electron oxidation of IAA by peroxidase giving a radical, which reacts with oxygen non-enzymically to regenerate $\mathrm{H}_{2} \mathrm{O}_{2}$ (19).

(c) Oxygen-consuming reaction catalyzed by the $\mathrm{H}_{2} \mathrm{O}_{2}$ complex of peroxidase, activated by $\mathrm{Mn}^{+2}(1,2)$.

(d) Oxidation by addition of $\mathrm{O}_{2}$, catalyzed by ferrous peroxidase, and not involving $\mathrm{H}_{2} \mathrm{O}_{2}$ (formation of ferrous from ferric peroxidase "activates" the enzyme and depends upon $\mathrm{H}_{2} \mathrm{O}_{2}$ ) [cf. tryptophan pyrrolase (16)].

The effects observed with $\mathrm{Mn}^{+2}$ are considered inconsistent with the type of mechanism proposed in $(c)$. According to it, $\mathrm{Mn}^{+2}$ should interact with the $\mathrm{H}_{2} \mathrm{O}_{2}$ complex of peroxidase to bring about the oxygen-consuming reaction, whereas $\mathrm{Mn}^{+2}$ did not promote when $\mathrm{H}_{2} \mathrm{O}_{2}$ was added, even though the oxygen-consuming reaction occurred. The effect of $\mathrm{H}_{2} \mathrm{O}_{2}$ on the oxygen kinetics is also contrary to $(c)$.

The idea (a) that the reaction depends upon more than one enzyme (oxidase and peroxidase), or on different catalytic centers of one enzyme which act at different steps in the reaction sequence, is not very attractive for several reasons. In the kinetics of such reaction sequences the rate coefficients for successive steps are generally to be multiplied, so that if the enzyme acted at two steps the reaction would be expected to be proportional to the square of the enzyme concentration, which it definitely is not. Further, no evidence of a requirement for enzyme activity different from peroxidase was detected in purification and thermal inactivation experiments (13).
That oxygen-consuming oxidation of IAA need not involve reaction of $\mathrm{O}_{2}$ with any enzyme is shown by the initiation of such oxidation by $\mathrm{Mn}^{+3}(8)$ and by nitrite (17) in the absence of enzymes.

The other two suggested mechanisms (b) and $(d)$ contrast sharply, for (b) presumes a peroxidative action of the enzyme and the existence of peroxy intermediates, whereas in $(d)$ the features of the reaction which have been ascribed above to the occurrence of catalytic intermediates must be interpreted at least in part in terms of the appearance of an "activated" (ferrous) form of the enzyme, and $\mathrm{H}_{2} \mathrm{O}_{2}$ is supposed not to be a reaction intermediate. The principal kinds of evidence (16) supporting mechanism $(d)$ for tryptophan pyrrolase were: $(i)$ catalase inhibited much more strongly at the start than when the reaction was under way; (ii) HCN inhibited strongly at first, but if added later caused only gradual inhibition, suggesting that the ferric form of the enzyme was no longer present; (iii) the ferrous enzyme was formed in the presence of tryptophan and $\mathrm{H}_{2} \mathrm{O}_{2}$.

While there was evidence in previously reported experiments (13) that a different (possibly ferrous) form of the IAA-oxidizing enzyme might be appearing in the presence of IAA, it is difficult to exclude the possibility that the results were due to experimental treatment (polyphenols or $\mathrm{CO}$ ) rather than a reflection of the IAA oxidation mechanism. Cyanide $\left(10^{-3} M\right)$ caused complete inhibition within $1 \mathrm{~min}$. when added after the start of the reaction $[(12)$, Table II].

In manometric experiments it was found that catalase inhibited IAA oxidation more strongly when added initially than after the steady state had been reached. The difference was not as great, however, as found for tryptophan pyrrolase (16); for example, $0.5 \mathrm{mg}$. catalase inhibited $45 \%$ when added initially and $13 \%$ when added after $20 \mathrm{~min}$.

We do not consider the results with catalase to be evidence against the existence of a peroxy intermediate other than $\mathrm{H}_{2} \mathrm{O}_{2}$. They do suggest that $\mathrm{H}_{2} \mathrm{O}_{2}$ itself is not a major intermediate. It was not found possible to derive kineties consistent with those 
observed, on the assumption that $\mathrm{H}_{2} \mathrm{O}_{2}$ is a principal intermediate.

Since Yamazaki [(19) and unpublished experiments] has demonstrated single electron oxidation of IAA by peroxidase and the resulting formation of free radicals, and since the existence of free radical intcrmediates makes explicable a variety of properties of the system, as well as its kinetics, we favor the type of mechanism indicated under $(b)$. If special forms of the enzyme are involved, we presume that their formation and disappearance is included in the kinetic description of the system discussed above.

The following reaction sequence of type (b) would exhibit kineties comparable with those observed in IAA oxidation, and is presented as a possible mechanism. Per represents peroxidase and Per II its peroxide complex II.

$$
\begin{aligned}
& \mathrm{IAA}+\operatorname{Per} \mathrm{II} \stackrel{k_{1}}{\longrightarrow} \mathrm{P} \cdot+\text { Per } \\
& \mathrm{P} \cdot+\mathrm{O}_{2} \stackrel{k_{2}}{\longrightarrow} \mathrm{PO}_{2} . \\
& \mathrm{PO}_{2} \cdot+\text { Per } \stackrel{k_{3}}{\longrightarrow} \mathrm{PO}_{2} \mathrm{H}+\text { Per II }
\end{aligned}
$$

$\mathrm{PO}_{2} \mathrm{H}$ is assumed to be an unstable hydroperoxide:

$$
\mathrm{PO}_{2} \mathrm{H} \stackrel{k_{4}}{\longrightarrow} \text { reaction products }
$$

but it also dissociates to some extent to yield radicals which can participate in the reaction, thus leading to initiation:

$$
\mathrm{PO}_{2} \mathrm{H} \stackrel{k_{5}}{\longrightarrow} \mathrm{P} \cdot+\cdot \mathrm{OOH}
$$

The peroxy radical may disappear by side reactions, may react with the enzyme to give a peroxide complex, or may react with IAA to give $\mathrm{P} \cdot$ and $\mathrm{H}_{2} \mathrm{O}_{2}$; any $\mathrm{H}_{2} \mathrm{O}_{2}$ formed will react with the enzyme to give a peroxide complex. These reactions result in initiation, and the possibility that $\mathrm{H}_{2} \mathrm{O}_{2}$ participates to some extent is thus apparent. However, to simplify analysis we assume that these reactions are relatively unimportant in initiation compared with reaction (7) followed by reaction (4).

The principal termination process is assumed to be

$$
\mathrm{PO}_{2} \cdot+\mathrm{P} \cdot \stackrel{k_{6}}{\longrightarrow} \mathrm{PO}_{2} \mathrm{P}
$$

Reactions (3-8) can be shown to give the steady-state kinetics

$$
v=\frac{k_{1} k_{2} k_{3} k_{5} \cdot f(\mathrm{IAA})\left[\mathrm{O}_{2}\right][\mathrm{E}]}{2 k_{1} k_{4} k_{6} \cdot f(\mathrm{IAA})+k_{2} k_{3} k_{5}\left[\mathrm{O}_{2}\right]}
$$

in which $[\mathrm{E}]$ represents the concentration of peroxidase, and $f(\mathrm{IAA})$ the dependence of reaction (3) on IAA concentration.

When the second term in the denominator of Eq. (9) is large compared to the first term, the rate is limited by reaction $(3)$. This corresponds to the situation under $\mathrm{H}_{2} \mathrm{O}_{2}$ saturation, when almost all the peroxidase has been converted to Per II. In the ordinary steady state, in which the rate is considerably less, the second term cannot be large compared with the first term.

Although Eq. (9) corresponds pretty well with the observed kineties, it is doubtful (but difficult to test) whether increasing the $\mathrm{O}_{2}$ concentration would raise the rate to the $\mathrm{H}_{2} \mathrm{O}_{2}$ saturating value. However, this could easily be due to the occurrence of other termination reactions, for example between two $\mathrm{PO}_{2}$. radicals.

Promotion by phenol under $\mathrm{H}_{2} \mathrm{O}_{2}$ saturation suggests that the following reaction sequence, in which $\mathrm{ROH}$ represents the phenol and $\mathrm{RO} \cdot$ its oxidation product,

$$
\begin{aligned}
\mathrm{ROH}+\mathrm{Per} \mathrm{II} & \rightarrow \mathrm{RO} \cdot+\text { Per } \\
\mathrm{RO} \cdot+\mathrm{IAA} & \rightarrow \mathrm{P} \cdot+\mathrm{ROH}
\end{aligned}
$$

goes more rapidly than reaction (3).

\section{REFERENCES}

1. Akazawa, T., and Conv, E. E., J. Biol. Chem. 232, 403 (1958).

2. Chance, B., J. Biol. Chem. 197, 577 (1952).

3. Galston, A. W., Bonner, J., and Baker, R. S., Arch. Biochem. Biophys. 42, 456 (1953).

4. Goldacre, P. I., Australian J. Sci. Research B4, 293 (1951).

5. Gordon, S. A., And Weber, R. P., Plant Physiol. 26, 192 (1951).

6. Kentex, R. H., Biochem. J. 59, 110 (1955).

7. Kentex, R. H., Biochem. J. 61, 353 (1955).

8. Maclachlay, G. A., and Waygoon, E. R., Physiol. Plantarum 9, 321 (1956).

9. Maclachlan, G. A., and Waygood, E. R., Can. J. Biochem. Physiol. 34, 1233 (1956). 
10. Mudd, J. B., And Burris, R. H., J. Biol. Chem. 234, 2774 (1959).

11. Mudo, J. B., And Burris, R. H., J. Biol. Chem. 234, 3281 (1959).

12. RAY, P. M., Arch. Biochem. Biophys. 64, 193 (1956).

13. Ray, P. M., Arch. Biochem. Biophys. 87, 19 (1960).

14. Sivgle, W. V., Nature 180, 250 (1957).
15. Stutz, R. E., Plant Physiol. 32, 31 (1957).

16. Tayaka, T., and Krox, W. E., J. Biol. Chem. 234, 1162 (1959).

17. Tonhazy, N. E., and Pelczar, M. J., Scicnce 120, 141 (1954).

18. Waygoood, E. R., OAKs, A., and Maclachlan, G. A., Can. J. Botany 34, 905 (1956).

19. Yamazaki, I., axd Soczo, H., Arch. Biochem. Biophys. 86, 294 (1960). 